\title{
IMPACT OF SCULPTURES IN LANDSCAPE DESIGN: CASE OF GREATER IQBAL PARK, LAHORE
}

\author{
Sadia Farooq ${ }^{1}$, Mohammad Arif Kamal²* \\ ${ }^{1}$ Dept. of Interior Design, University of Home Economics \\ Lahore, Pakistan \\ ${ }^{2}$ Architecture Section, Aligarh Muslim University \\ Aligarh, India
}

*Corresponding author: architectarif@gmail.com

\begin{abstract}
Introduction: A landscaped area is always appealing when designed according to a certain theme and purpose, as is the case with the sculptures in the Greater lqbal Park. Purpose of the study: We aimed to analyze the influence of ornamental sculptures on people visiting the Greater lqbal Park situated in Lahore, Pakistan. The objective was to evaluate the importance of the sculptures' presence in the park, to review the visitors' opinions on the subject, and to analyze how the sculptures blend in with other elements of the park. Methods: An important aspect of the study is the combination of data collected through observations, pictures, and questionnaires. Results and discussion: $65 \%$ of visitors to the park are satisfied with the sculptures' placement and the lighting around them. The sculptures depicting a bent tree, birds, musical instruments, and a peacock are aesthetically pleasing and alluring for the visitors. The reliefs reference art from the Mughal era, and the material is durable, tough, and weather-resistant. Conclusions: The visitors like to have sculptures in the park, which increases the park's appeal, especially for children, who can learn visual lessons about shapes and history. The study will help designers with creating variety and inspiring interest through sculptures, especially those related to historical events and complementing their surroundings.
\end{abstract}

\section{Keywords}

Sculptures, landscape design, Greater lqbal Park, Lahore, Pakistan.

\section{Introduction}

The landscape is the visible aspect of an area, its landforms and interactions with natural or man-made features. Landscapes have a wide variety of features, including: the physical elements of geophysically defined landforms, such as mountains and hills as well as water bodies, such as rivers, lakes, ponds, and seas; living organisms, including indigenous vegetation; man-made elements, including different forms of land use, buildings, and structures; and transitory elements, such as lighting and weather conditions (Dumas et al., 2007; Woudstra and Fieldhouse, 2000). Landscapes can be both natural and man-made (also called built landscapes). The natural landscapes on Earth include mountain landscapes, coastal landscapes, and riverine landscapes. Natural landscapes are made up of a variety of geographical features known as landforms: hills, caves, valleys, etc. (Booncham et al., 2011).

Parks, by contrast, are designed by humans to provide an area of natural, semi-natural, or planted space, set aside for human enjoyment and recreation or the protection of wildlife or natural habitats. Parks may consist of grassy areas, rocks, soil, and trees, but may also contain buildings and other artifacts, such as monuments, fountains, or playground sculptures. People value the time they spend in city parks, whether playing basketball, having a picnic, or more. Along with these expected leisure amenities, parks can also provide measurable health benefits, from direct contact with nature and a cleaner environment to opportunities for physical activity and social interaction (Cushing and Pennings, 2017; Woudstra and Fieldhouse, 2000).

Public parks are often the "engine" that drives tourism in many communities. In a simplified tourism model, visitors use some mode of transportation to leave their homes and travel to attractions, which are supported by various kinds of services, such as hotels/motels, restaurants, and retailing (Farooq and Kamal Arif, 2020). The attractions and support services provide information and promote their offerings to target groups that they have identified as potential visitors (Booncham et al., 2018). Parks are commonly thought of as the venue for "fun and games", but that is only one of the roles they play in a metropolitan environment. Urban parks, which broadly include parkland, plazas, landscaped boulevards, waterfront promenades, and public gardens, significantly define the layout, real estate value, traffic flow, public events, and the civic culture of our communities. With open spaces, our cities 
and neighborhoods are enhanced with sculptures and gain beauty, breathing room, and value. City parks and open spaces improve our physical and psychological health, strengthen our communities, and make our cities and neighborhoods more attractive places to live and work. Numerous studies have demonstrated the social, environmental, economic, and health benefits that parks bring to a city and its people. Including parks and recreation facilities in urban planning can promote active lifestyles, build healthy communities, and lower healthcare and transportation costs (Farooq, 2020; Özgüner and Kendle, 2006).

The park reviewed in our paper is the Greater lqbal Park, formerly known as Minto Park and renamed after renovation and expansion. This urban park is located on the outskirts of the Walled City of Lahore, Pakistan. Noted as the home of Minare-Pakistan, the 125-acre park includes an artificial lake that spreads over a four-acre territory with an 800 -feet-long musical fountain. Other attractions include a soft rail, a library, an open-air gym, and a food court (Fatima et al., 2017; Shah et al., 2018; Yahya, 2020). The objectives of this study can be summarized as follows:

- To analyze the blend between the sculptures and other elements of the park.

- To evaluate the importance of the sculptures' presence in the park from the visitors' standpoint.

- To analyze the visitors' opinions on the presence of sculptures in the park.

\section{Literature Review}

"A sculpture is a three-dimensional art form that provides an important visual way of understanding form and space". A sculpture can be figurative or abstract, but regardless, its purpose is to make humans aware of themselves and their environment (Woudstra and Fieldhouse, 2000). There are many types of sculptures: portrait busts, allegorical and equestrian figures, funerary sculptures, garden sculptures, figurines. Abstraction and assemblage are the dominant forms of modern sculpture.

\section{Garden Sculptures}

Many gardens have sculptures that are used to enhance the beauty of the surrounding environment. The landscaper must choose the site for the garden sculpture carefully and thoughtfully, in order to enhance the garden and give emphasis to design and plantings throughout the year. The height of the sculpture in relation to the viewer's eye level, as well as the height of plants and other sculptures, is a crucial aspect of the setting. This cannot be perfectly controlled, as the eye level varies depending on body height (between 1.40 and $1.80 \mathrm{~m}$ ) and changes according to the laws of perspective as the viewer approaches (Booncham and Chantachon, 2019).

If the sculpture rests on the grass, it gives a more casual impression: symbolically, the sculpture shares the same ground as humans, animals, and gardens; it grows from the same earth that nurtures the surrounding vegetation. Manipulating closeness and distance to the sculpture through garden design is an important tool in controlling the viewer's experience. The impact of the sculpture is made up of its different views, varying in angles and distance. Garden designers often use sculptures as focal points. Focusing on the sculpture slows down the viewer's journey through the garden's expanse, as they stop and examine the sculpture. This allows for discovering the garden gradually rather than sweeping through it and having a superficial experience; the garden becomes enlarged in the viewer's perception. Texture - the surface material quality - is a crucial aesthetic dimension of both garden design and sculpture. It is explored through touch, but also visually. Sculpture textures may vary depending on the material and the use of tools (Lambert, 2006; Warkentin, 2010).

Color in sculptures and plants is yet another means of manipulating the space and directing the visitor's attention: it can be used to create depth or simulate flatness. Warm colors like reds, yellows, and oranges make the object visually closer to the viewer. Cool colors like greens and blues visually move the object further away. Complementary colors are attracted to one another (red to green, blue to orange, yellow to purple) and catch the viewer's attention. Bright colors stand out against more gray or toned-down colors (Dumas et al., 2007; Ives, 2018).

Relevance of Sculptures in Landscape Design

Sculptures can do what plants alone cannot: they add symbolic meaning, trigger positive memories, and often touch the human heart, creating a sensation of peace and inner joy. Sculptures function as an integral part of many ceremonies and events. Often unnoticed, they give a visual reference for emotional experiences throughout the passage of human life. Outdoor sculptures are always a surprising delight. Sculptures can make a very dramatic statement, and their placement is important. Some of them are site-specific, some are functional, and some are welcoming. Sculptures can also be transformed by the wind, season, or time of day (Ives, 2018). One of the most beautiful attractions in Lahore is the Greater lqbal Park, which displays fountains and flowers. This landscaped attraction is a project of the Lahore Development Authority (LDA). The idea of this park was to convert the barren area between the Iqbal Park and Badshahi Mosque into something more entertaining, like a theme park.

\section{Park}

Historical Background of the Greater Iqbal

The Minto Park (now the Greater lqbal Park) was named after Lord Minto Gilbert Elliot (1751-1814), the Ninth Indian Governor-General between 1807 and 1813. The vast grassy stretches around Minar- 
e-Pakistan are most famous for hosting the All-India Muslim League's gathering that passed the Pakistan Resolution of March 23, 1940, which provided the decisive impetus to the movement leading up to the division of British India in 1947. The 203-foot high Minar-e-Pakistan tower was built between 1960 and 1968 at the Greater Iqbal Park to commemorate the first official call for a separate homeland for the Muslims of India. This monument was completed on October 21, 1968, at an estimated cost of Rs $7,058,000$. The money was raised by imposing an additional tax on cinema and horse racing tickets at the demand of Akhtar Husain, the then Governor of West Pakistan (Fatima et al., 2017; Yahya, 2020).

The park was renovated by the Punjab government within 13 months, at a cost of Rs 981 million. The Greater lqbal Park lies on the outskirts of the Walled City, which happens to be the cultural heart of Lahore. The salient features of the Greater Iqbal Park in Lahore are the statues of QuaidE-Azam, Allama Iqbal, Fatima Jinnah, and Sir Syed Ahmed Khan, along with the renovated and preserved Minar-E-Pakistan, thematic food courts depicting cultures and heritages of all provinces of Pakistan, the Heritage Museum that highlights the history of the Pakistan Movement, elaborate walkways, gardens, pavements, dancing fountains, and a baradari pavilion. Since this park is near the historic Mughal Buildings, its pavements and fountains are laid out in the Mughal architecture style, featuring geometric patterns similar to those used in the historic buildings. On weekends, multiple families come out here to enjoy picnics in an environment of waterfalls and fountains. This project is indeed a great relief for the citizens, as it has provided the much-needed parking and recreational facilities (Shah et al., 2018; Yahya, 2020).

\section{Research Methodology}

This paper is based on quantitative research,

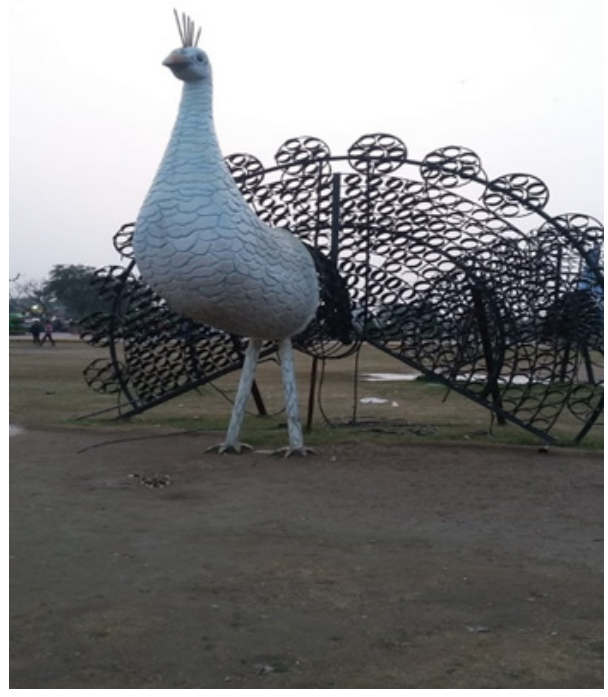

Figure 1. Sculpture of a peacock in the Greater lqbal Park (source: the authors) which was done by collecting data through observations, pictures, and questionnaires. The questionnaires were filled by the visitors who were coming to the park. They needed to answer questions on how important they found the sculptures and how the sculptures influenced them during their visit to the park. The scope of this study is parks with ornamental sculptures in Pakistan, made for the general public to visit. The sample is the Greater lqbal Park in Lahore, where many huge ornamental sculptures are present.

\section{Data Analysis}

The study was divided into two parts: visual analysis and survey analysis, as explained below:

\section{Visual Analysis}

Figure 1 shows a sculpture of a peacock in the Greater lqbal Park, a symbol of peace and beauty. As the peacock is considered the symbol of beauty, the sculpture is surrounded by plain grasslands to highlight its importance. It enhances the beauty of the park.

Figure 2 shows a great blend of art and culture in the Greater lqbal Park. This sculpted relief features factual depictions of various historical events. The relief has images of Pakistan's freedom-fighting leaders and views of different historical buildings, reminding the Pakistani people of their history and worthy place in the world.

Figure 3 shows a tree-like sculpture with a metal body and colorful flower pots. It enhances the beauty of the park; moreover, the pots can be used for planting small plants.

Figure 4 shows a light pole encircled by a sculpture that enhances its beauty and makes it more appealing to visitors.

Figures 5 and 6 show different functional sculptures that can be used for planting small plants in pots, while also enhancing the beauty of the park.

Figure 7 shows a musical instrument sculpture.

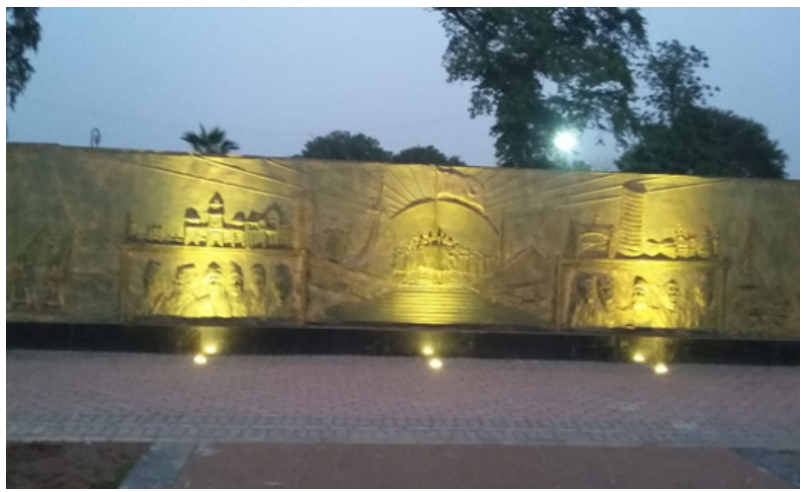

Figure 2. Relief in the Greater Iqbal Park (source: the authors) 
It is an art form that has a profound impact on the people visiting the park.

Figure 8 shows a colorful sculpture of a sparrow that gives the viewer a chance to observe the bird's beauty and innocence from close-up.

Figure 9 shows a bud coming out of a flower pot. Its shape enhances its surroundings.

Figure 10 shows a book enclosed in a glass case, documenting a series of historical events that occurred in the past years.

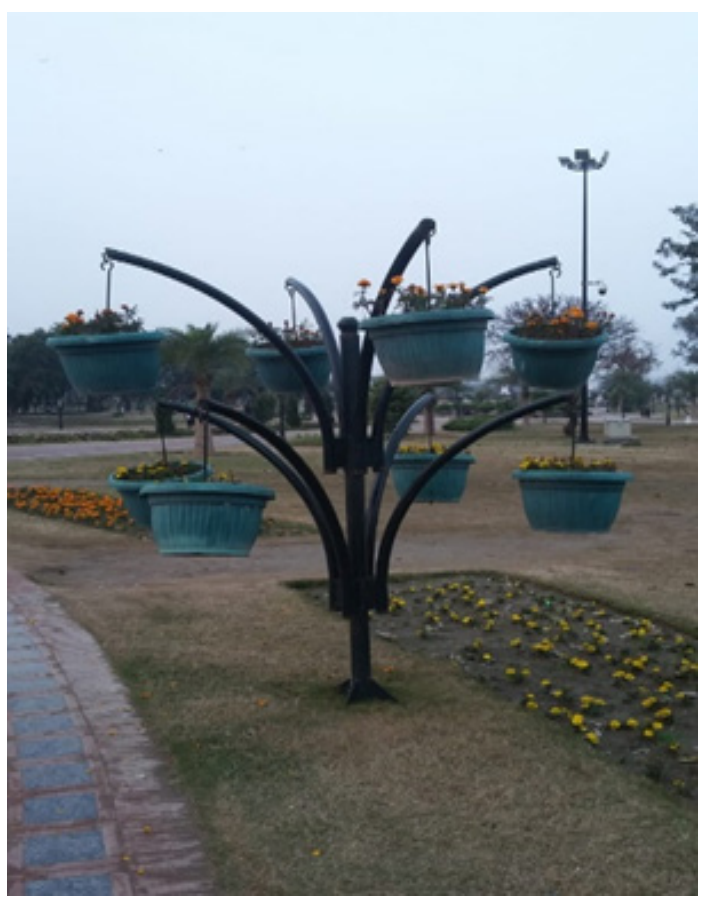

Figure 3. Tree-like sculpture for hanging flower pots (source: the authors)

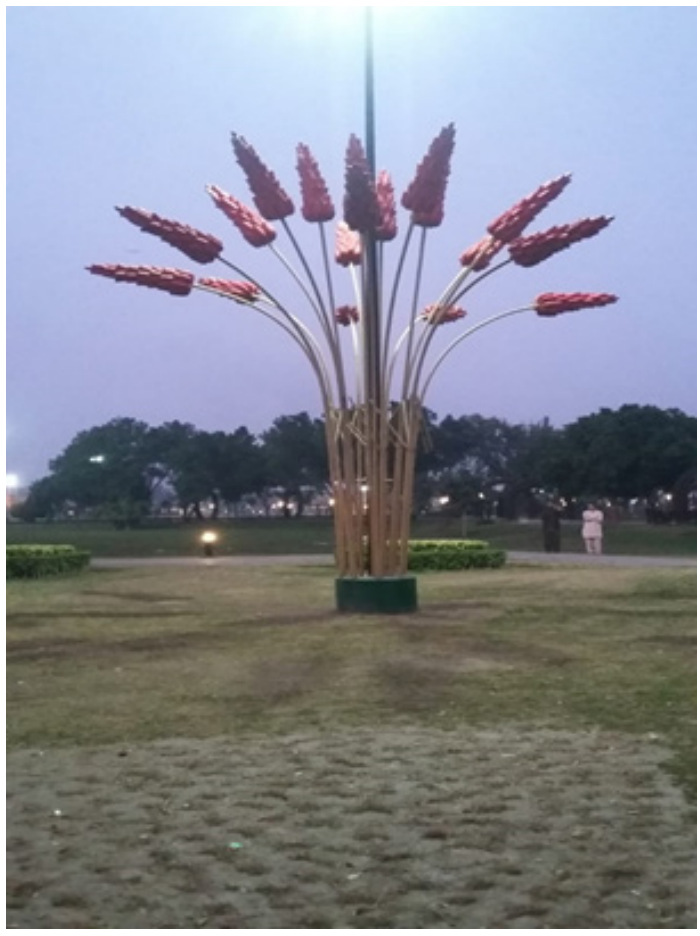

Figure 4. Sculpture with a light pole in the Greater lqbal Park (source: the authors)
Figure 11 shows a small roofed area where park visitors can enjoy a meal and rest in a fragrant shady place.

Figure 12 shows a passageway covered completely in ornamental plants. It recreates a natural environment.

Figure 13 shows a sculpted peacock, with a white body and yellow flowers for feathers.

\section{Survey Analysis}

The analysis of the survey aims to evaluate the

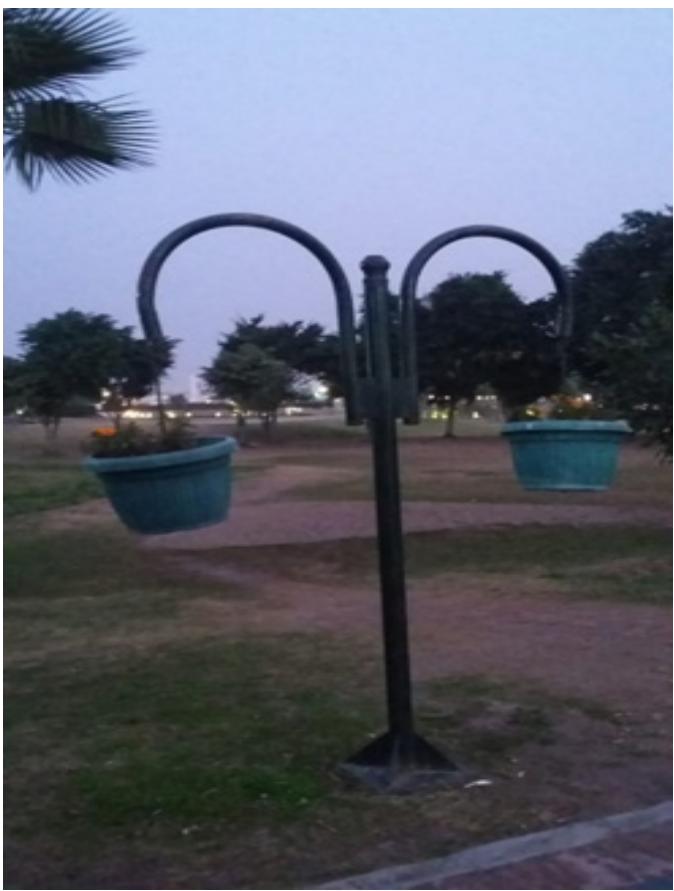

Figure 5. Pole with flower pots in the Greater Iqbal Park (source: the authors)

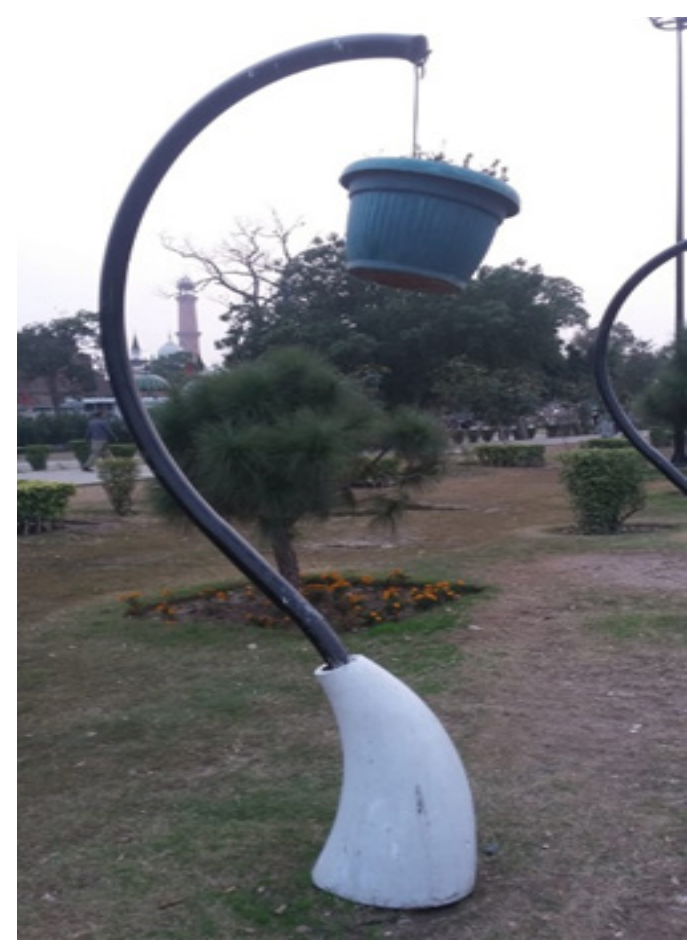

Figure 6. Curved pole with a flower pot in the Greater lqbal Park (source: the authors) 


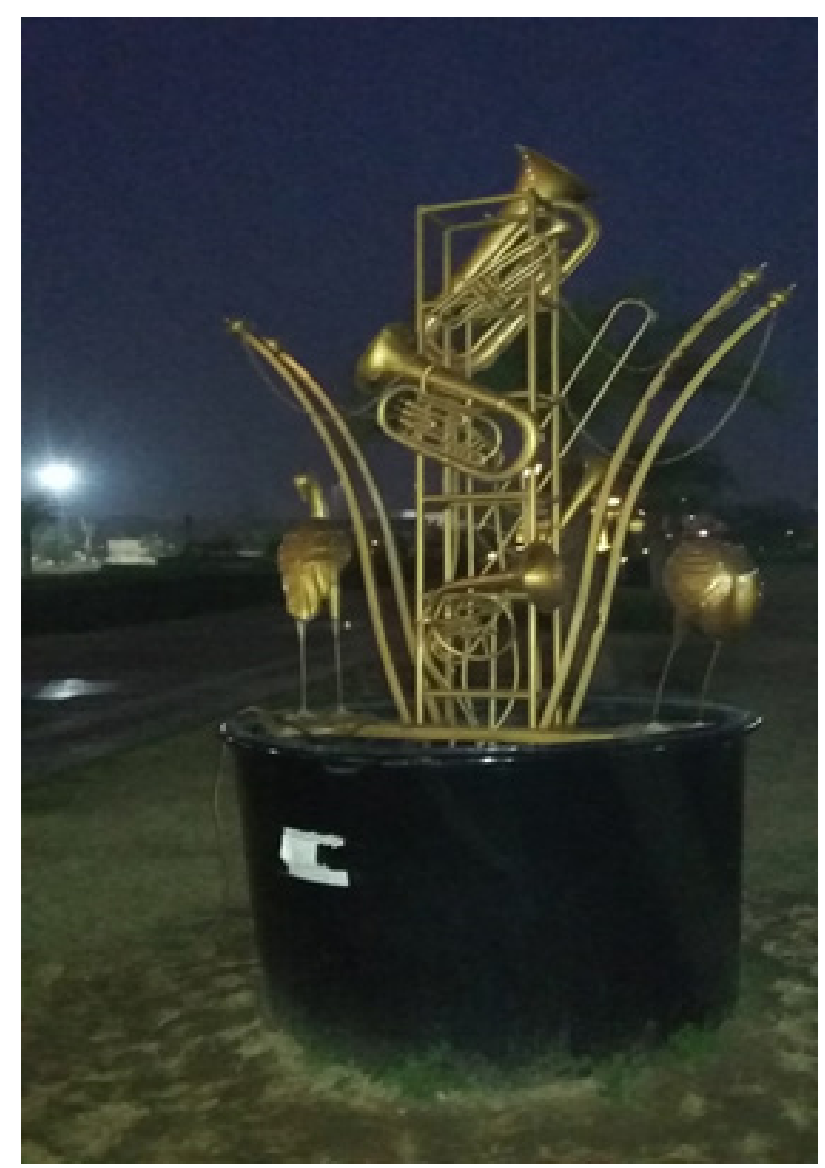

Figure 7. Sculpture of musical instruments in the Greater lqbal Park (source: the authors)

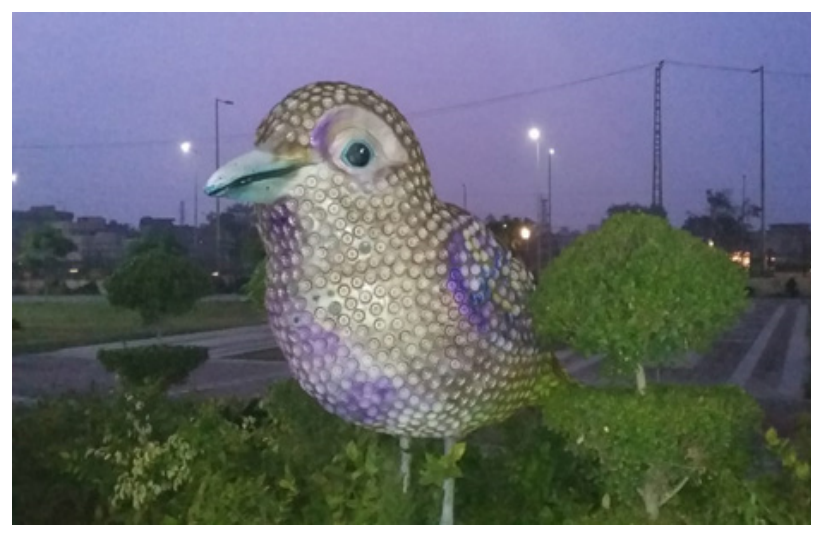

Figure 8. Sculpture of a bird in the Greater lqbal Park (source: the authors)

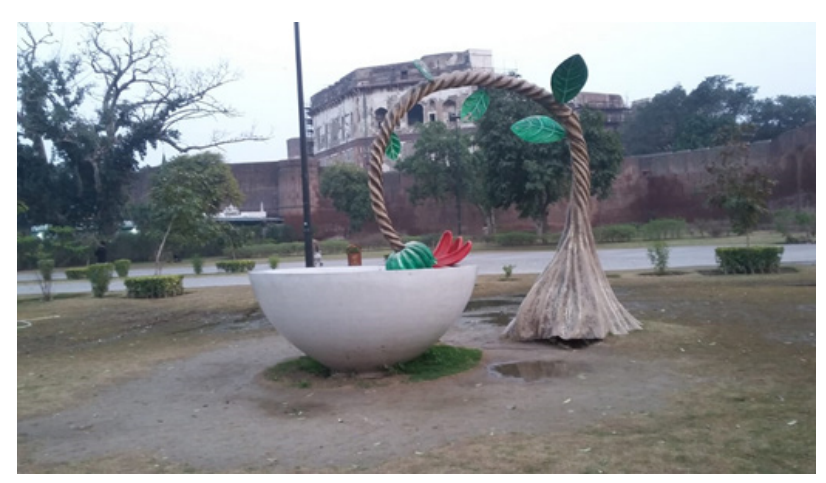

Figure 9. Sculpture of a bent bud in the Greater lqbal Park (source: the authors)

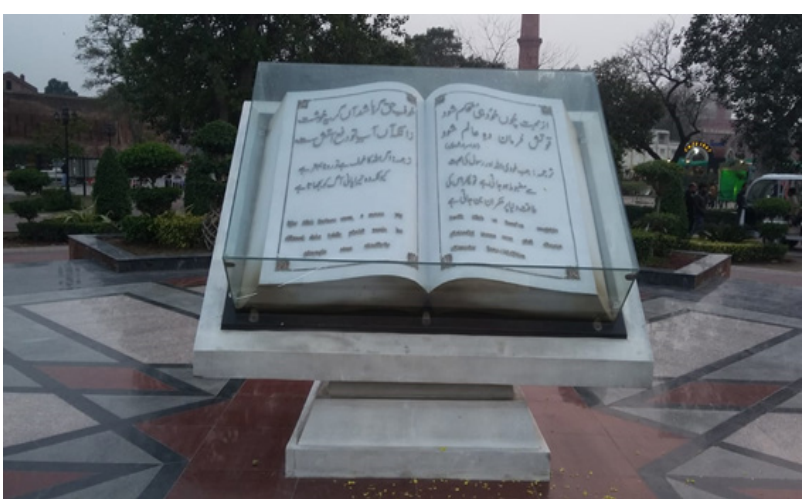

Figure 10. Sculpture of a book in the Greater Iqbal Park (source: the authors)

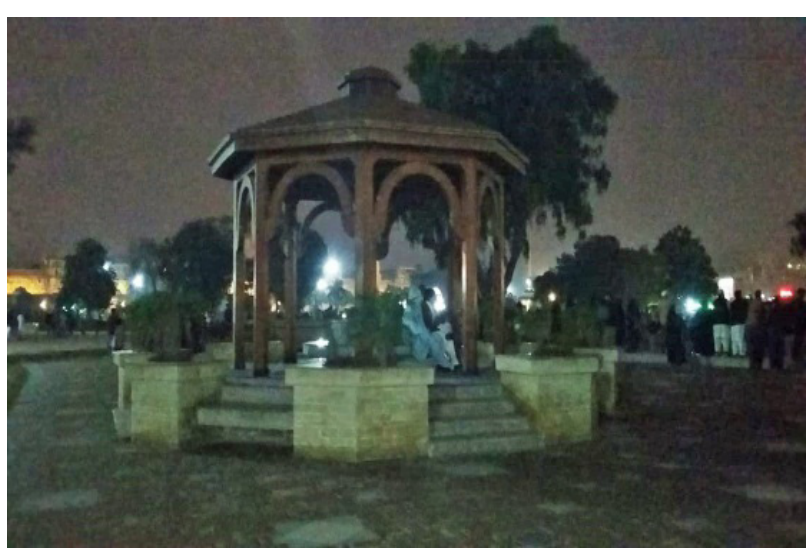

Figure 11. Gazebo in the Greater Iqbal Park (source: the authors)

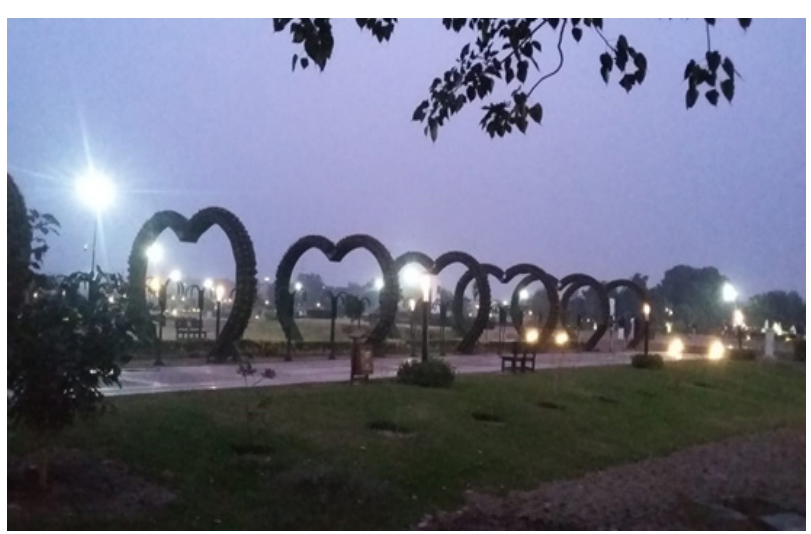

Figure 12. Heart-shaped sculptures with flowers in the Greater lqbal Park (source: the authors)

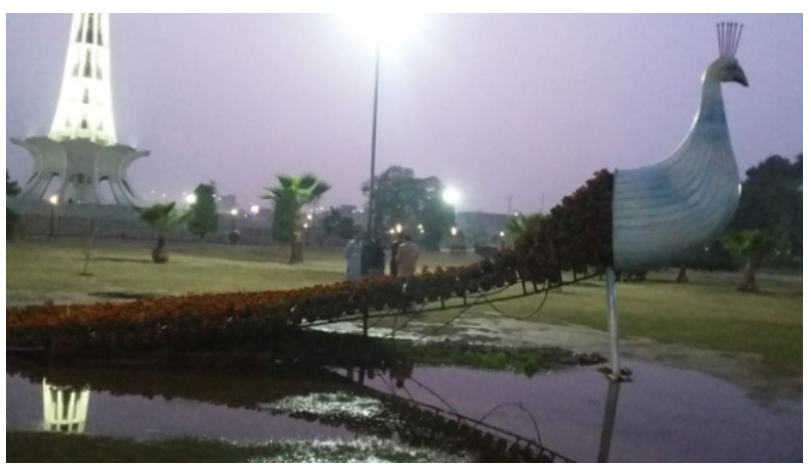

Figure 13. Sculpture of a peacock with flowers on its tail (source: the authors) 
influence of the ornamental sculptures in the park and analyze the visitors' opinions on the matter.

Figure 14 shows that $9 \%$ of respondents like the sculptures, $64 \%$ like the trees and flowers, and $27 \%$ like the dancing fountain at the Greater lqbal Park. We can conclude that $64 \%$ of visitors to the Greater lqbal Park enjoy looking at its trees and flowers.

Figure 15 shows that $30 \%$ of visitors spend $10-$ 20 minutes in the Greater lqbal Park, 25\% spend $30-60$ minutes, and $45 \%$ spend more than 1 hour. The conclusion is that $45 \%$ of those who come to the Greater lqbal Park spend more than 1 hour there.

Figure 16 shows that $75 \%$ of visitors feel relaxed, $10 \%$ do not feel relaxed, and $15 \%$ feel neutral. We can conclude that $75 \%$ of people feel relaxed during their time in the Greater lqbal Park.

Figure 17 shows that $65 \%$ of visitors think that the park has a positive impact, $5 \%$ think that the park

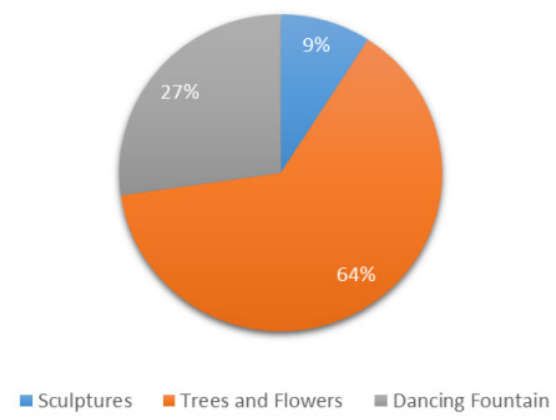

Figure 14. Opinions on the presence of sculptures in the park

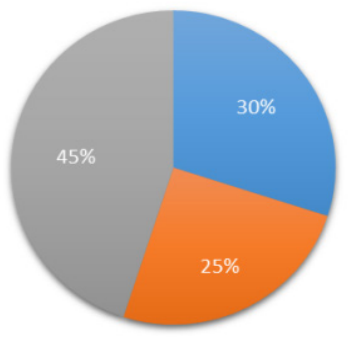

=10-20 $\min =30 \mathrm{~min}-1$ hour $=$ More than 1 hour

Figure 15. Duration of stay in the park

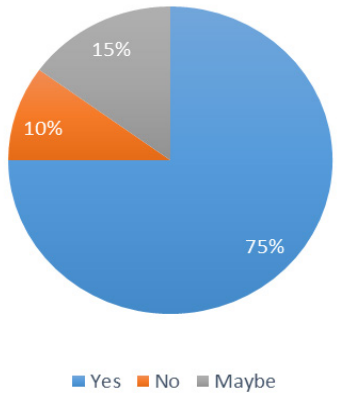

Figure 16. Impressions of visitors staying in the park has a negative impact, and $30 \%$ think that the park has a neutral impact. We can therefore summarize that $65 \%$ of people think that the Greater lqbal Park has a positive impact on them.

Figure 18 shows that $45 \%$ of respondents think that having sculptures is necessary for a park, $15 \%$ think that it is not necessary, and $40 \%$ think that it can go either way.

Figure 19 shows that $79 \%$ of respondents are comfortable with the placement of sculptures in the Greater lqbal Park, $10 \%$ think that the placement of sculptures is poor, and $11 \%$ are neutral on the subject. Our conclusion is that $79 \%$ of visitors are comfortable with the placement of sculptures in the Greater lqbal Park.

Figure 20 shows that $35 \%$ of respondents like realistic sculptures, $20 \%$ like abstract sculptures, and $45 \%$ like both. This prompts the conclusion that

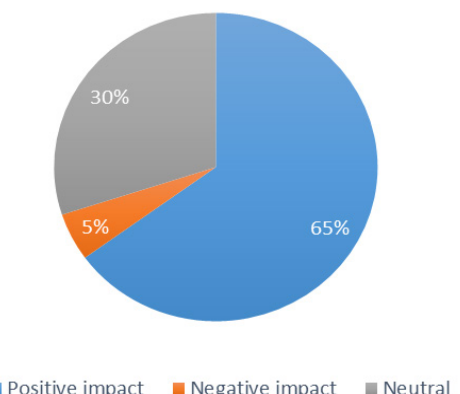

Figure 17. Park's impact on visitors

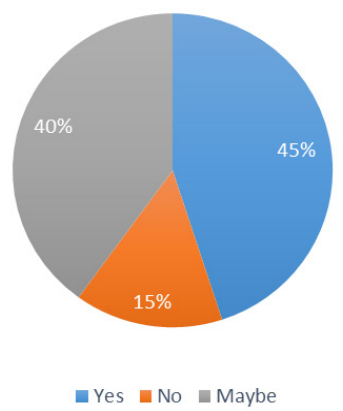

Figure 18. Necessity of sculptures in the park

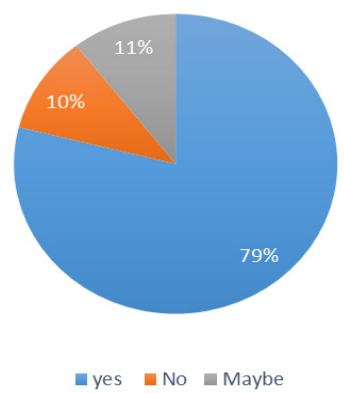

Figure 19. Comfort with the placement of sculptures in the park 
$45 \%$ of park visitors enjoy both realistic and abstract sculptures.

Figure 21 shows that $75 \%$ of respondents like sculptures that are decorated with flowers, $20 \%$ do not like such sculptures, and $5 \%$ are uncertain about whether or not they like them. The conclusion, therefore, is that $75 \%$ of respondents are appreciative of sculptures that are decorated with flowers.

Figure 22 shows that $40 \%$ of respondents characterize the sculptures of the Greater lqbal Park as historical, $30 \%$ think the sculptures are modern, and $30 \%$ think the sculptures are cultural. In other words, $40 \%$ of people think that the sculptures of the Greater lqbal Park are historical.

Figure 23 shows that $75 \%$ of people think that the sculptures of the Greater lqbal Park have good lighting around them, $5 \%$ think that the sculptures do not have good lighting, and $20 \%$ are not sure about

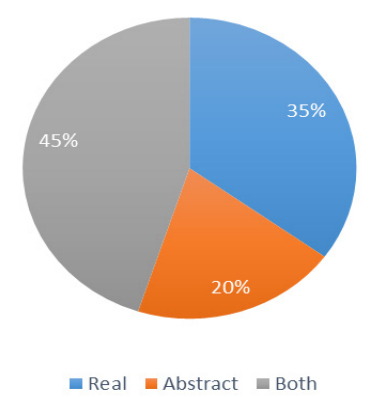

Figure 20. Responses to sculpture realism

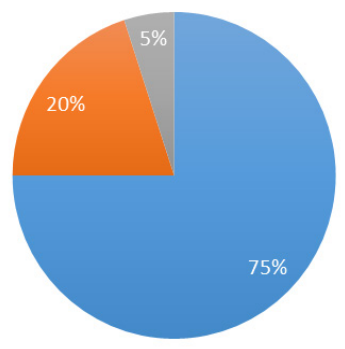

- Real $=$ Abstract $=$ Both

Figure 21. Responses to sculptures decorated with flowers

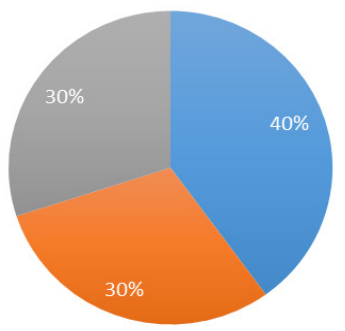

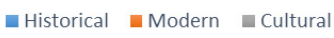

Figure 22. Types of sculptures that visitors can distinguish the lighting. We can conclude that $75 \%$ of the people visiting the Greater Iqbal Park think that the local sculptures have good lighting around them.

Figure 24 shows that $15 \%$ of people think that the sculptures are easily recognizable by children, $20 \%$ think that they are not easily recognizable, and $65 \%$ think that they might be easily recognizable by children. We conclude that $65 \%$ of respondents are uncertain about whether children can recognize the sculptures.

Figure 25 shows that $60 \%$ of respondents think that the sculptures of the Greater lqbal Park help children with recognizing figures related to historical events, $5 \%$ think that they do not help, and $35 \%$ think that they might do so. We conclude that $60 \%$ of people consider the sculptures of the Greater lqbal Park helpful when it comes to children's education.

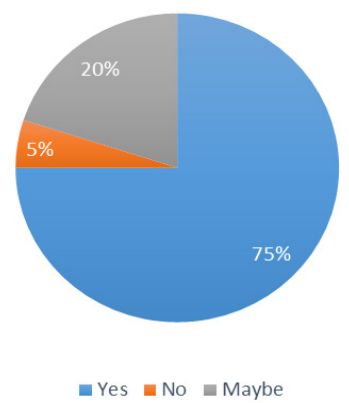

Figure 23. Sculpture lighting quality

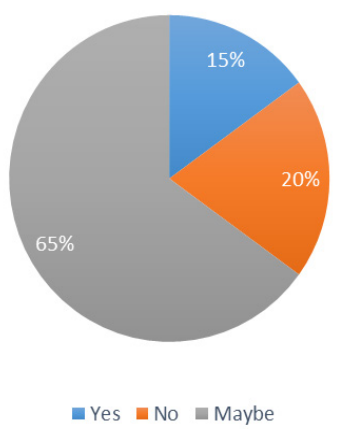

Figure 24. Recognition of the sculptures by children

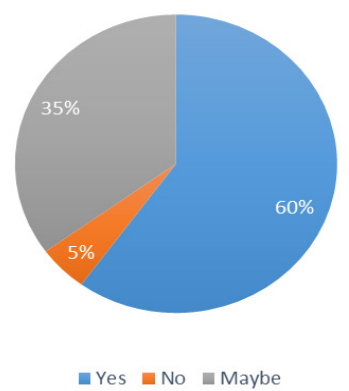

Figure 25. Sculptures' help with children's learning about national history 
Figure 26 shows that $70 \%$ of people think that sculptures add beauty to the landscape, $5 \%$ think that sculptures do not add beauty, and $25 \%$ think that sculptures might add beauty to the landscape. We conclude that $70 \%$ of respondents think that sculptures do add beauty to the park's landscape.

Figure 27 shows that $60 \%$ of visitors like metal sculptures, $10 \%$ like plastic sculptures, and $30 \%$ like sculptures made of both plastic and metal. The conclusion is that metal sculptures are preferred by $60 \%$ of respondents.

Figure 28 shows that $30 \%$ of respondents think that the size of sculptures in the park is appropriate, $15 \%$ think that the size of the sculptures is not appropriate, and $55 \%$ think that the size might be appropriate. In conclusion, $55 \%$ of respondents believe that the size of sculptures in the Greater lqbal Park might be appropriate.

Figure 29 shows that $20 \%$ of people think that the park needs more sculptures, $10 \%$ think that the park does not need more sculptures, and $70 \%$ think that more sculptures might be needed in the park. In other words, $70 \%$ of respondents think that the Greater lqbal Park might need more sculptures.

\section{Summary and Conclusion}

The landscape encompasses the visible features of an area of land, often considered in terms of their aesthetic appeal. At the same time, a park is a large public garden or area of land used for recreation. It consists of grassy areas, rocks, and trees, as well as different sculptured elements.

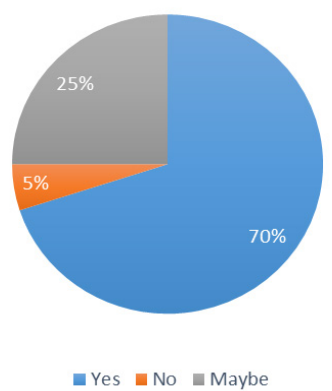

Figure 26. Adding beauty to the park with sculptures

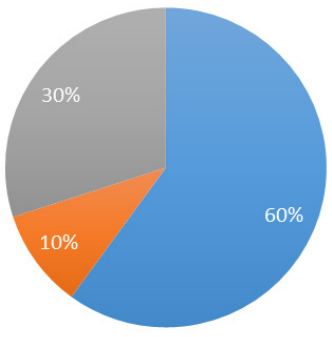

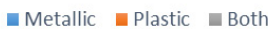

Figure 27. Visitors' attitude to the material used for sculptures
Sculpture is a branch of visual arts that operates in three dimensions. Their main function is to direct movement through space and to enclose space, as well as to add symbolic meaning. Designing a garden in a way that manipulates the perception of the sculptures' proximity or distance is an important tool for controlling the viewer's experience. Color in sculpture is yet another means of manipulating space and directing the viewer's attention.

The Greater lqbal Park was formerly known as Minto Park, renamed after renovation and expansion. This urban park is located on the outskirts of Lahore, Pakistan. It has a number of appealing features: a soft rail, a library, an open-air gym, and a food court, an outstanding plantation, sculptures, as well as elaborate walkways, gardens, pavements, dancing fountains, and a baradari pavilion. Since this park is near the historic Mughal Buildings, its pavements and fountains are laid out in the Mughal architecture style, featuring geometric patterns similar to those used in the historic buildings.

This paper analyzed and focused on the importance of, and need for, different sculptures in any park, with special reference to the Greater lqbal Park. The sculptures of a bent tree, birds, a musical instrument, a peacock, etc. are aesthetically pleasing and alluring for the visitors. The paper examined the materials used for making these sculptures, their placement, and how they attract viewers through their form and shape. While the park covers a huge area for recreation, most of the sculptures can be easily

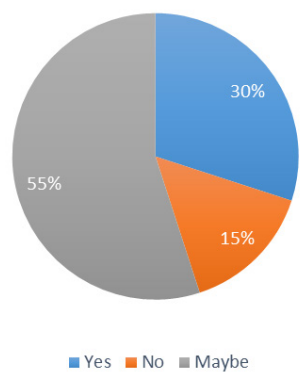

Figure 28. Visitors' opinions on the size of sculptures in the park

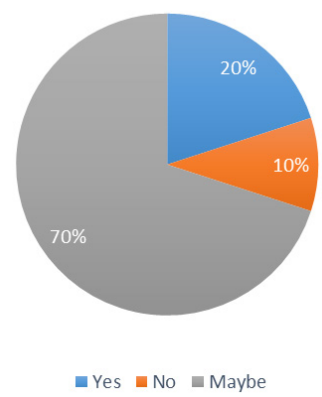

Figure 29. Need for more sculptures 
seen from the distance because of their size. We acknowledged the purpose of different sculptures, noting that they are beautifully carved and symbolic. The materials used include bricks, cement, clay, steel, and plaster of Paris. The integrated topiaries and other flowers embellish the environment, while also creating a healthy atmosphere for the visitors. The pavements are decorated with heart-shaped arches. Most of the seating arrangements are inside gazebos, which both enhance the space and protect the visitors against unfavorable climatic conditions.

The visitors are enjoying the landscape of the Greater lqbal Park. Most of them are comfortable with the placement and sizes of sculptures. The visitors, especially children, responded positively to having sculptures in the park because these sculptures are easily recognizable and are creating an educational environment for the children. References to the Mughal Buildings can be easily seen in various sculptures, such as the relief sculptures, especially considering the proximity of the Walled City to the park. The material used for making the sculptures is durable, tough, and weather-resistant. The finished product is instantly appealing to the eye. Most of the park visitors consider that there are enough sculptures in the Greater lqbal Park. Adding more sculptures may make the environment cluttered and confusing. The Greater lqbal Park is a comfortable place where people can take their families and show them the great history of Pakistan. The sculptures are a great addition to the park and the authors personally liked every sculpture. Our favorite, however, was the relief showing certain historical events. 


\section{References}

Booncham, A. and Chantachon, S. (2019). Contemporary sculptures: Decoding the body of aesthetic knowledge suitable for public parks. Journal of Cultural Approach, Vol. 20, No. 37, pp. 62-71.

Booncham, A., Chantachon, A. and Lao-Akka, S. (2011). Contemporary sculptures: Decoding the body of aesthetic knowledge suitable for public parks. American Journal of Applied Sciences, Vol. 8, Issue 12, pp. 1302-1306. DOI: 10.3844/ ajassp.2011.1302.1306.

Booncham, A., Chantachon, A. and Lao-Akka, S. (2018). Analysis of the aesthetics of contemporary sculptures suitable for public parks in Thailand. Thai Journal of East Asian Studies, Vol. 22, No. 1, pp. 2-18. DOI: 10.14456/ijeas.2018.1.

Cushing, D. F. and Pennings, M. (2017). Potential affordances of public art in public parks: Central Park and the High Line. Proceedings of the Institution of Civil Engineers - Urban Design and Planning, Vol. 170, Issue 6, pp. 245-257. DOI: 10.1680/jurdp.16.00042.

Dumas, C. F., Burrus, R. T. Jr., Diener, E., Payne, J. and Rose, J. (2007). Valuing the recreational benefits of sculpture in public parks. Journal of Park and Recreation Administration, Vol. 25, No. 2, pp. 29-41.

Farooq, S. (2020). Psychological impact of landscape principles on human beings: A case study of Safari Villas Park Bahria Town, Lahore, Pakistan. Pure and Applied Biology, Vol. 9, No. 3, pp. 1820-1830. DOI: 10.19045/bspab.2020.90194.

Farooq, S. and Kamal Arif, M. (2020). Analysis of green living walls: Individual awareness about its functional value and aesthetical quality. Civil Engineering and Architecture, Vol. 8, No. 4, pp. 444-449. DOI: 10.13189/cea.2020.080406.

Fatima, H. S., Abrar, A. and Shehzadi, R. (2017). Assessment of the Impacts on Water Quality of the Area by Landscaping Activities of Greater lqbal Park Project, Lahore, Pakistan. Journal of Coastal Zone Management, Vol. 20, Issue 3, 1000448. DOI: $10.4172 / 2473-3350.1000448$.

Ives, C. (2018). Public parks, private gardens: Paris to Provence. New York: Metropolitan Museum of Art, 204 p.

Lambert, D. (2006). The meaning and re-meaning of sculpture in Victorian public parks. In: Eyres, P. and Russell, F. (eds.) Sculpture and the Garden. London; New York: Routledge, pp. 99-110.

Özgüner, H. and Kendle, A. D. (2006). Public attitudes towards naturalistic versus designed landscapes in the city of Sheffield (UK). Landscape and Urban Planning, Vol. 74, Issue 2, pp. 139-157. DOI: 10.1016/j.landurbplan.2004.10.003.

Shah, S. A., Shah, A. A. and Li, X. (2018). Assessment of the history and cultural inclusion of Public Art in Pakistan. Preprints. DOI: 10.20944/preprints201802.0117.v1.

Warkentin, J. (2010). Creating memory: A guide to outdoor public sculpture in Toronto. Toronto: Becker Associates, 347 p. Woudstra, J. and Fieldhouse, K. (eds.) (2000). The regeneration of public parks. London: E \& FN Spon, 196 p.

Yahya, A. A. (2020). The construction of ideology in political discourse: A deictic analysis. International Journal of Applied Linguistics \& English Literature, Vol. 9, Issue 2, pp. 1-14. DOI: 10.7575/aiac.ijalel.v.9n.2p.1. 